\title{
A Multicriterion Decision Support Methodology For Audit Opinions: The Case Of Audit Reports Of Distressed Firms In Turkey
}

Burcu Adiloğlu, Istanbul University, Turkey Bengu Vuran, Istanbul University, Turkey

\begin{abstract}
The audit report represents the most important part of the audit process and it is the sole communication medium between the auditor and the users of the financial statements. After accounting scandals, auditors' responsibility for assessing the appropriateness of audit opinions has become the subject of much debate in the auditing profession and considerable research by academics. This increased attention is due to the fact that auditors appear to be reluctant to disclose audit opinions other than unqualified. Indeed, many companies in the year prior to bankruptcy receive an audit report in which going concern uncertainty is not disclosed. The research of this paper is designed to examine the relationship between the type of audit reports and firm failure. Logistic regression analysis is applied to test the model of audit opinion decision with a sample of financially distressed firms operating in manufacturing sector in Istanbul Stock Exchange (ISE) between the period of 1998-2006. The results reveal that the audit opinions of distressed firms indicate the auditors fail to issue appropriate audit opinions one year prior to failure.
\end{abstract}

Keywords: Audit Opinion; Financial Failure; Going-Concern; Bankruptcy; Logistic Regression

\section{INTRODUCTION}

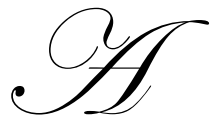

uditing is a systematic process of objectively obtaining and evaluating evidence regarding assertions about economic actions and events to ascertain the degree of correspondence between those assertions and established criteria and communicating results to interested users. (American Accounting Association, 1973)

The audit report is the final step in the entire audit process. Audit reports are essential to audit engagements because they communicate the auditor's findings. Users of financial statements rely on the auditor's report to provide assurance on the company's financial statements. (Arens, Elder, Beasley, 2006)

According to International Standards on Auditing; the purpose of an audit is to enhance the degree of confidence of intended users in the financial statements. This is achieved by the expression of an opinion by the auditor on whether the financial statements are prepared, in all material respects, in accordance with an applicable financial reporting framework. In the case of most general purpose frameworks, that opinion is on whether the financial statements are presented fairly, in all material respects, or give a true and fair view in accordance with the framework.

Shortly after the Enron scandal, numerous other scandals involving corporate giants (e.g. Tyco, WorldCom, Xerox, Adelphia and Ahold), brokerage firms (e.g., Merrill Lynch), Stock exchanges (e.g., the Newyork Stock Exchange), mutual fund managers (e.g. Piper Jaffrey), and several large public accounting firms were uncovered. 
The Enron scandal alone weakened investor confidence in stock market, but the subsequent series of scandals caused a crisis of confidence in the integrity of the entire system of public ownership and accountability in the United States. (Messier, Glower, Prawitt, 2008) After these accounting scandals, auditors' responsibility for assessing the appropriateness of audit opinions has become much more crucial subject in the auditing profession.

Specifically, in a case where a firm's financial statements are not showing any signals of financial distress (e.g. presence of adverse financial ratios, debt default), the auditor's opinion may assume a more important role to stakeholders, since the publicly available data do not lead to an expectation of imminent failure. Also, financial statements users have constantly expected auditors to give such early warning signals under the premise that auditors are in the best position to determine when companies are in a situation of potential failure and report this doubt to interested parties. Therefore, a high quality audit is one where the audit opinion conveys information to financial statement users that is not otherwise perceptible from the financial statement themselves. (Miglani, Ahmed, Henry, 2010)

International Standard on Auditing (ISA), 570- Going Concern deals with the auditor's responsibilities in the audit of financial statements relating to management's use of the going concern assumption in the preparation of the financial statements. Under the going concern assumption, an entity is viewed as continuing in business for the foreseeable future. Financial statements and, in particular, all general purpose financial statements, are therefore prepared on a going concern basis, unless management either intends to liquidate the entity or to cease operations, or has no realistic alternative but to do so. When the use of the going concern assumption is appropriate, assets and liabilities are recorded on the basis that the entity will be able to realize its assets and discharge its liabilities in the normal course of business. (ISA 570) The auditor's responsibility is to evaluate the appropriateness of management's use of the going concern assumption in the preparation of the financial statements and conclude whether there is a material uncertainty about the entity's ability to continue as a going concern that need to be disclosed in the financial statements. The auditor evaluates the appropriateness of management's use of the going concern assumption even if the financial reporting framework used in the preparation of the financial statements does not include an explicit requirement for management to make a specific assessment of the entity's ability to continue as a going concern. (ISA 570)

According to ISA 570, the objectives of the auditor are:

(a) To obtain sufficient appropriate audit evidence regarding the appropriateness of management's use of the going concern assumption in the preparation of the financial statements;

(b) To conclude, based on the audit evidence obtained, whether a material uncertainty exists related to events or conditions that may cast significant doubt on the entity's ability to continue as a going concern; and

(c) To determine the implications for the auditor's report.

Auditing standards indicate that the auditor has a responsibility to evaluate whether there is a substantial doubt about an entity's ability to continue as a going-concern for a reasonable period of time. A reasonable period of time is considered to be no more than one year beyond the date of the financial statements being audited. For example, if an entity has violated certain debt covenants or is in default on its debt, the debt holders may call immediate payments. In such circumstances, the entity may unable to meet its cash requirements and may have to seek bankruptcy protection or liquidation. (Messier, Glower, Prawitt, 2008)

The following are examples of events or conditions that, individually or collectively, may cast significant doubt about the going concern assumption. This listing is not all-inclusive nor does the existence of one or more of the items always signify that a material uncertainty exists. (ISA 570)

\section{FINANCIAL}

- $\quad$ Net liability or net current liability position.

- $\quad$ Fixed-term borrowings approaching maturity without realistic prospects of renewal or repayment; or excessive reliance on short-term borrowings to finance long-term assets.

- Indications of withdrawal of financial support by debtors and other creditors. 
- $\quad$ Negative operating cash flows indicated by historical or prospective financial statements.

- $\quad$ Adverse key financial ratios.

- Substantial operating losses or significant deterioration in the value of assets used to generate cash flows.

- $\quad$ Arrears or discontinuance of dividends.

- Inability to pay creditors on due dates.

- Inability to comply with other terms of loan agreements.

- $\quad$ Change from credit to cash-on-delivery transactions with suppliers.

- Inability to obtain financing for essential new product development or other essential investments.

\section{OPERATING}

- $\quad$ Loss of key management without replacement.

- $\quad$ Loss of a major market, franchise, license, or principal supplier.

- $\quad$ Labor difficulties.

- $\quad$ Shortages of important supplies.

\section{OTHER}

- $\quad$ Non-compliance with capital or other statutory requirements.

- $\quad$ Pending legal or regulatory proceedings against the entity that may, if successful, result in claims that are unlikely to be satisfied.

- Changes in law or regulation or government policy expected to adversely affect the entity.

According to ISA 570, when the use of the going concern assumption is appropriate in the circumstances but a material uncertainty exists, the auditor shall conclude whether the financial statements:

(a) Adequately describe the principal events or conditions that may cast significant doubt on the entity's ability to continue as a going concern and management's plans to deal with these events or conditions; and

(b) Disclose clearly that there is a material uncertainty related to events or conditions that may cast significant doubt on the entity's ability to continue as a going concern and, therefore, that it may be unable to realize its assets and discharge its liabilities in the normal course of business.

If adequate disclosure is made in the financial statements, the auditor shall express an unmodified opinion but shall include an Emphasis of Matter paragraph in the auditor's report to:

(a) Highlight the existence of a material uncertainty relating to the event or condition that may cast significant doubt on the entity's ability to continue as a going concern; and to

(b) Draw attention to the note in the financial statements that discloses the matters in the independent auditor's report.

If adequate disclosure is not made in the financial statements, the auditor shall express a qualified or adverse opinion. The auditor shall include specific reference in the auditor's report to the fact that there is a material uncertainty that may cast significant doubt about the entity's ability to continue as a going concern.

Before a firm is unable to continue as a going concern its financial ratios may deteriorate. However, in their opinion, a clearer sign of potential going concern problems would be difficulties a firm may encounter in fulfilling its debt obligations such as compliance with lending agreements or making scheduled payments. However, if default is occurred, if negotiation is under way, it is a clear warning signal to auditors of going concern problems. This paper provides evidence that a logistic regression model using publicly available financial data predicts whether an auditor will issue a going concern opinion prior to financial distress.

The rest of the paper is organized as follows: Section II provides a detailed survey of past studies. Section III explains the data (variables employed) and methodology while the results are presented in Section IV. Finally, Section $\mathrm{V}$ gives the conclusion. 


\section{LITERATURE REVIEW}

Auditor's responsibility for assessing the appropriateness of the going-concern assumption in the financial statements of their clients has become the subject of much debate in the auditing profession and considerable research by academics.

Due to the perceived expectations gap between auditors and financial statement users who place greater responsibility on the auditor for disclosing going concern uncertainty, statistical corporate failure models are seen as a tool that could assist auditors in making more accurate going concern judgements.

Many previous papers documented the relationship between the issuance of going concern opinion and subsequent bankruptcy.

Altman \& McGough (1974) provided a link between bankruptcy prediction models and auditors' opinion decisions by comparing the accuracy of Altman's (1968) bankruptcy prediction model to auditors' opinions prior to bankruptcy event. They analyzed the model's prediction and auditors' opinion for 34 firms that filled bankruptcy during the 1970-1973 period. They reported that auditors' opinions signaled impending failure in only $46 \%$ of the cases.

Mutchler (1985) attempted to examine the audit opinions of "problem" companies. A problem company was defined as a company having one of the seven characteristics including being in liquidation or having negative net worth, negative cash flows, negative income from operations, negative working capital, current year loss or a current year earnings deficit. This study was designed to test the extent to which the going-concern opinion could be predicted using only publicly available information. The type of audit opinion could be used as a reinforcing signal, and cases in which the information and the opinions were consistent would justify more reliance on auditors' decisions.

Levitan \& Knoblett (1985) used multiple discriminant analysis to see if the financial statement variables were able to predict auditors' going-concern opinions. They compared companies that received going-concern opinions to companies that received unmodified opinions. The results showed that the financial statement variables were useful in distinguishing the two types of opinions.

Dopuch, Holthausen, \& Leftwich (1987) examined whether or not financial and market variables were able to predict first-time qualified opinions. Although they investigated multiple types of qualifications including goingconcern, litigation and asset realization, the model performed best when used to predict going-concern opinions. They distinguished their study from that of Levitan \& Knoblett (1985) by using not only financial statement variables, but also market predictor variables such as company beta and the length of time listed on a public exchange.

Chen \& Church (1992) examined the ability of debt default variable to explain audit opinions. Their model included previously tested financial statement variables, but found that the debt default status of a company provided incremental explanatory power. The results suggest that it may be easier to justify a going concern modified opinion when the company is already in default. They also presented a separate analysis of the audit opinions issued to companies that filed for bankruptcy. Their results show that failing companies are more likely to receive an unmodified opinion the year before the bankruptcy filing, when they are not in default.

Hopewood, McKeown, \& Mutchler (1994) compare the accuracy of auditor and model predictions of firm failure of 134 bankrupt and 160 non-bankrupt firms for the time period of 1974-1985. They found that financial statement ratio-based bankruptcy prediction models do not outperform auditor opinion qualifications for going concern issues in predicting firm failure.

Lennox (1999) evaluated and explained the accuracy and informativeness of audit reports in identifying failing companies. The results of the study showed that a bankruptcy model could be more accurate than audit reports in a hold-out period as well as in the estimation sample. It was also shown in the results that audit reports did 
not signal useful incremental information about the probability of bankruptcy. It is also found in the study that audit reports did not reflect publicly available information about financial distress. In particular, the probability of bankruptcy varied across industry sectors and decreased as the economy moved out of recession, however, this was not reflected by audit reporting. This suggests that auditors might need to give greater consideration to macroeconomic and industry events when forming audit opinions. In addition, lagged audit reports were important determinants of audit reporting but did not help to identify failing companies. Therefore, strong persistence in reporting also reduced the accuracy of audit reports.

Greiger et al. (2005) examine the prior audit opinion issued for 226 firms that entered into bankruptcy during the years 2000 through 2003.They also compare audit opinions in the post-December 2001 with audit opinions for bankruptcies from an earlier period. They find that auditors are more likely to issue going-concern modified opinions in the post-December 2001 period than in the earlier period.

\section{DATA \&RESEARCH METHODOLOGY}

The purpose of this research is to determine the extent to which auditors' going-concern opinion decisions can be predicted using publicly available information.

The research described in this paper is designed to examine the relationship between the going concern opinion and publicly available information. Logistic regression analysis is used to test models of going concern opinion decision with a sample of manufacturing companies that received a going concern opinion.

The sample of the companies used in this research is composed of only problem companies because the auditor must first identify a company as having a problem in some sense prior to making the going-concern opinion decision.

The analysis is restricted to financially distressed companies. To define financial stress, the presence of the following measures are investigated: (1) defaulting on loan obligations,(2) making an explicit agreement with creditors to reorganize debt structure (3) going bankruptcy. The year of failure for unsuccessful firms is selected as the year in which the firm undergoes financial distress. This information is gathered inspecting the "company news" section in the web site of Istanbul Stock Exchange (ISE).

The sample consists of 33 manufacturing firms underwent financial distress between the period of 1998 to 2006. The financial statements and audit reports are collected from Istanbul Stock Exchange web site. The analysis is conducted by SPSS 17. The distribution of industries of companies are shown in Table 1 and Figure 1.

Table 1: Companies By Sector

\begin{tabular}{|l|c|}
\hline \multicolumn{1}{|c|}{ Industry } & Number of Companies \\
\hline Electricity & 2 \\
\hline Chemical, Petroleum, Plastic & 3 \\
\hline Basic Metal & 3 \\
\hline Textile, Leather & 13 \\
\hline Food, Beverage & 4 \\
\hline Wood, Paper, Printing & 1 \\
\hline Nonmetal Mineral Products & 1 \\
\hline Technology & 1 \\
\hline Metal Products, Machinery & 5 \\
\hline Total & $\mathbf{3 3}$ \\
\hline
\end{tabular}




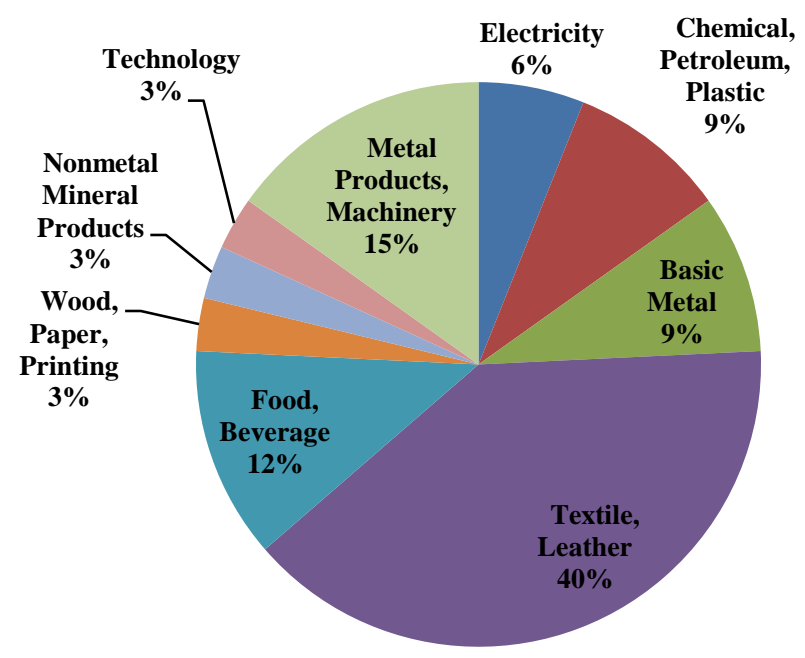

Figure 1: Percentage Of Companies By Sector

Financial failure year of the companies are also shown in Table 2 and Figure 2.

Table 2: Number Of Companies By Years

\begin{tabular}{|c|c|}
\hline Year & Number of Distressed Companies \\
\hline 1998 & 5 \\
\hline 1999 & 8 \\
\hline 2000 & 2 \\
\hline 2001 & 9 \\
\hline 2002 & 4 \\
\hline 2003 & 1 \\
\hline 2004 & 1 \\
\hline 2005 & 1 \\
\hline 2006 & 2 \\
\hline Total & $\mathbf{3 3}$ \\
\hline
\end{tabular}

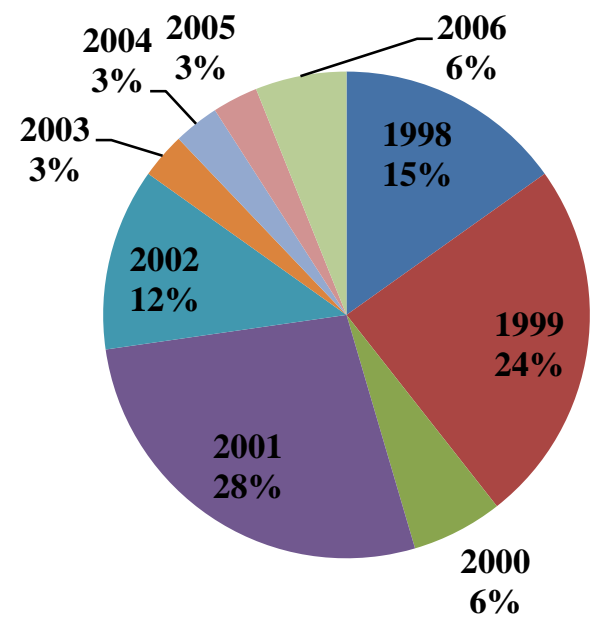

Figure 2: Percentage Of Companies By Years 
The type of audit reports are shown in Table 3 and the types of audit companies are displayed in Table 4 .

Table 3: Type Of Audit Report

\begin{tabular}{|l|c|}
\hline \multicolumn{1}{|c|}{ Type of Audit Report } & Number of audit reports \\
\hline Going-concern opinion issued & 5 \\
\hline No going-concern opinion issued & 28 \\
\hline Total & $\mathbf{3 3}$ \\
\hline
\end{tabular}

Table 4: Audit Company

\begin{tabular}{|l|c|}
\hline \multicolumn{1}{|c|}{ Audit Company } & Number of audited companies \\
\hline Big 4 & 2 \\
\hline Other audit companies & 31 \\
\hline Total & 33 \\
\hline
\end{tabular}

Figure 3 and Figure 4 show the distribution of types of audit reports and types of audit companies.

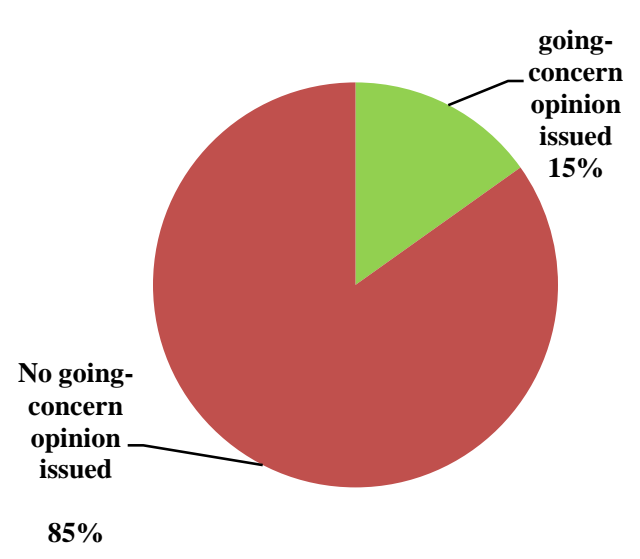

Figure 3: Audit Report Type

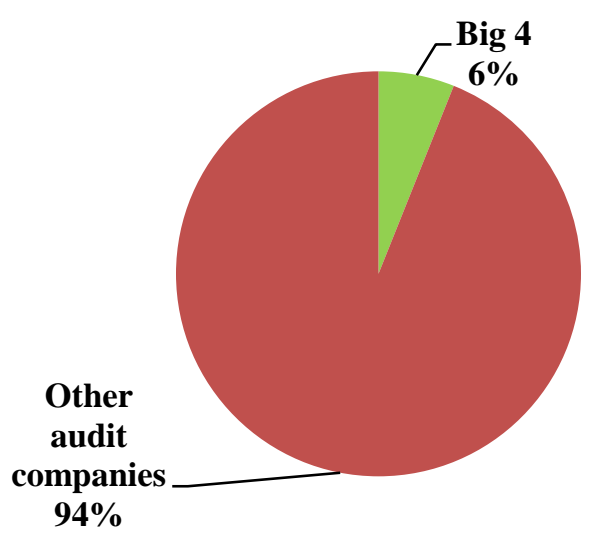

Figure 4: Percentage of Audit Companies 
The relationship between the audit opinion prior to financial distress and financial ratios is examined using a logistic regression to estimate the following model:

$$
\begin{aligned}
& \mathrm{GC}_{\mathrm{i}}=\mathrm{b}_{0}+\mathrm{b}_{1} \mathrm{SIZE}_{\mathrm{i}}+\mathrm{b}_{2} \mathrm{EBIT}_{2} \mathrm{TA}_{\mathrm{i}}+\mathrm{b}_{3} \mathrm{RE}_{\mathrm{i}}+\mathrm{b}_{4} \mathrm{TD}_{-} \mathrm{TA}_{\mathrm{i}}+\mathrm{b}_{5} \mathrm{CA}_{-} \mathrm{CL}_{\mathrm{i}}+\mathrm{b}_{6} \mathrm{CFFO}_{-} \mathrm{I}_{\mathrm{i}}+\mathrm{b}_{7} \mathrm{FAT}_{\mathrm{i}}+ \\
& \mathrm{b}_{8} \mathrm{RLAG}_{\mathrm{i}}+\mathrm{b}_{9} \mathrm{BIG} 4+\mathrm{b}_{10} \mathrm{PROB}_{\mathrm{i}}
\end{aligned}
$$

In table 5, the definitions of variables employed are given.

Table 5: Definitions Of Variables

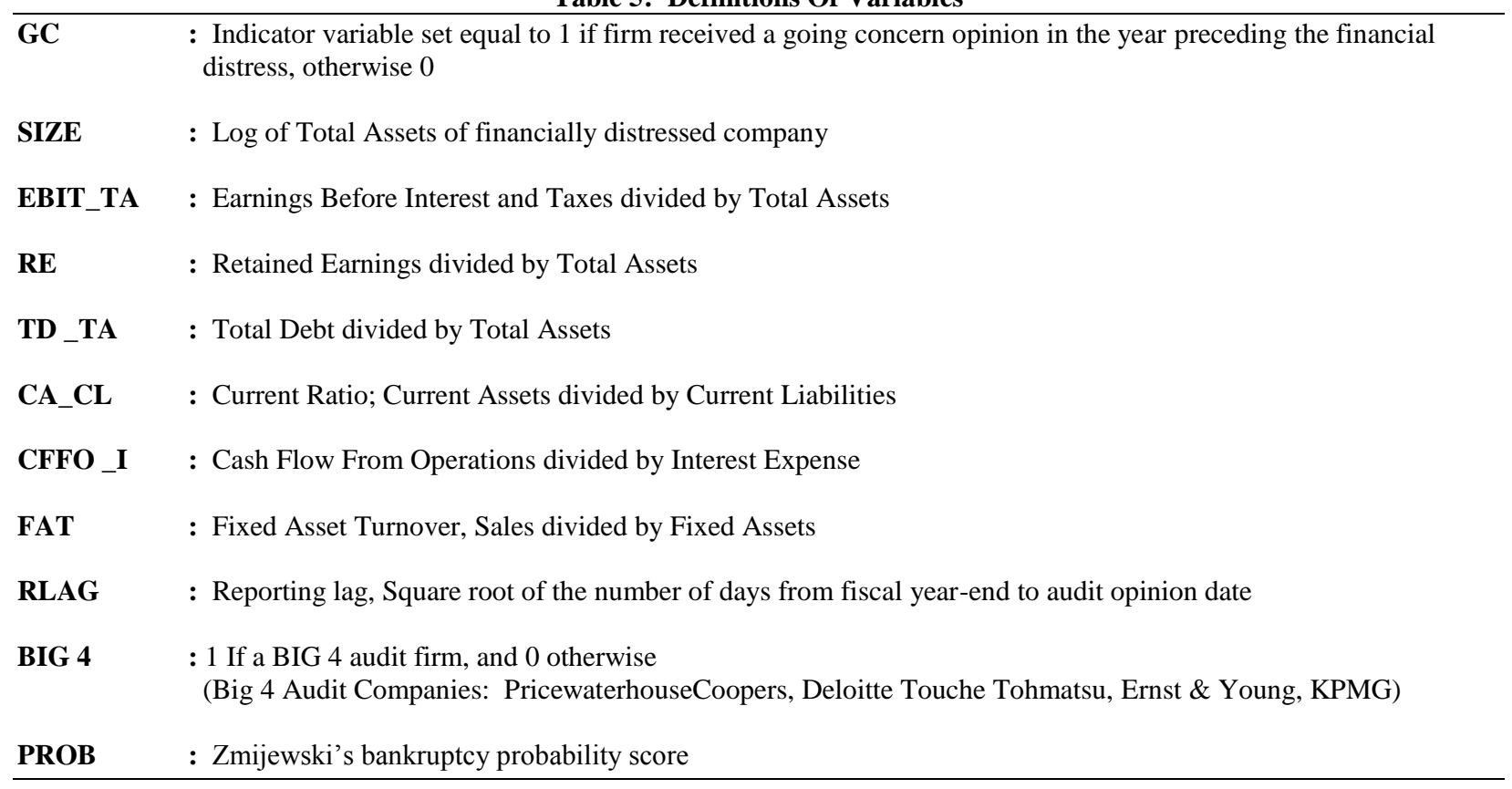

Consistent with prior researches; the firm size is measured by log total assets. The financial ratios are designated after a detailed literature review. Reporting lag is measured by the square root of the number of days from the fiscal year-end to the date of the audit opinion. BIG 4 variable is used to test the auditor size effect on the issuance of a going-concern opinion, because the auditing literature (Mutchler J. F., 1986), suggest that in certain situations small audit firms are less inclined to issue going-concern opinions than are large firms. The PROB variable represents the Zmijewski's bankruptcy probability score which is developed as a summary measure of financial distress. Zmijewski model is built up on a large sample of New York and American Stock Exchange companies. The model contains the common elements of a bankruptcy prediction model, namely, profitability, leverage and liquidity ratios. The statistic is calculated as follows:

\section{$B^{*}=-4,803$ - 3,6 Net Income / Total Assets + 5,4 Total Debt / Total Assets - 0,1 Current Assets / Current Liabilities}

The higher values of B indicate greater probabilities of bankruptcy. 


\section{EMPRICAL FINDINGS}

Logistic regression analysis is conducted to test the relationship between the ten variables mentioned above and the audit opinion decisions of financially distressed companies in Turkey. Stepwise procedure is applied in order to eliminate the multicollinearity between the independent variables.

Before the estimation process begins, Hosmer and Lemeshow test is used to measure the overall fit of the model. This statistical test measures the correspondence of the actual and the predicted values of the dependent variable. The null and alternative hypotheses to assess the overall model fit are;

$\mathbf{H}_{\mathbf{0}}: \quad$ The hypothesized model fits the data.

$\mathbf{H}_{1}$ : $\quad$ The hypothesized model does not fit the data.

Table 6: Hosmer And Lemeshow Test Results For Overall Fit Of Logistic Regression Model

\begin{tabular}{|l|c|c|c|}
\hline Step & Chi-square & df & Sig. \\
\hline 3 & 10,616 & 8 & 0,224 \\
\hline
\end{tabular}

Hosmer and Lemeshow Test assesses the overall fit of Logistic Regression Model. As seen in Table 6, for $10 \%$ significance level, the null hypothesis is accepted (Sig. 22,4\%).

Table 7: Variables Of Logistic Regression Model

\begin{tabular}{|l|c|c|c|c|c|c|}
\hline \multicolumn{1}{|c|}{ Variables } & b & SE & Wald & df & Sig. & Exp (b) \\
\hline Fat & 0,052 & $-0,031$ & 2,913 & $\mathbf{1}$ & 0,088 & 1,054 \\
\hline Ebit_ta & $-4,481$ & 3,815 & 1,379 & $\mathbf{1}$ & 0,084 & 0,011 \\
\hline Big 4 & $-2,712$ & 1,634 & 2,757 & $\mathbf{1}$ & 0,097 & 0,066 \\
\hline Constant & $-0,317$ & 1,436 & 0,049 & $\mathbf{1}$ & 0,825 & 0,728 \\
\hline
\end{tabular}

The Wald statistic is used to assess statistical significance of coefficients. All variables are significant at alpha level of $10 \%$. The sign of the original coefficients indicates the direction of relationship. A positive coefficient increases the probability whereas the negative value decreases the predicted probability, because the original coefficients are expressed in terms of logit values.

Using Table 7, the logistic regression model can be written as,

L = -0,317 - 2,712 Big4 - 4,481 Ebit_ta + 0,052 Fat

Table 8: The Model Summary

\begin{tabular}{|c|c|c|c|}
\hline Step & $\mathbf{- 2 ~ L o g ~ L i k e l i h o o d ~}$ & Cox \&Snell R $^{\mathbf{2}}$ & ${\text { Nagelkerke } \mathbf{R}^{\mathbf{2}}}$ \\
\hline $\mathbf{1}$ & 24,040 & 0,115 & 0,201 \\
\hline $\mathbf{2}$ & 20,177 & 0,213 & 0,371 \\
\hline $\mathbf{3}$ & 17,683 & 0,270 & 0,471 \\
\hline
\end{tabular}

Table 8 gives the model summary. The Nagelkerke $\mathrm{R}^{2}$ indicates the explanatory power of the model and 2 Log Likelihood ( $-2 \mathrm{LL}$ ) represents the sum of the square of error terms. As it is seen in Table 8, the explanatory power of significant variables is $47,1 \%$. and the $-2 \mathrm{LL}$ term is gradually decreases and indicates that the the last model (step 3) is the most suitable one. 
Table 9: The Classification Accuracy of The Model

\begin{tabular}{|l|c|c|c|c|}
\hline \multicolumn{2}{|c|}{ Observed } & \multicolumn{2}{c|}{ Opinion } & \multicolumn{2}{c|}{ Predicted } \\
\hline & & 0,00 & 1,00 & \\
\hline Opinion & 0,00 & 28 & 0 & 60 \\
\hline Overall Percentage & 1,00 & 2 & 3 & \\
\hline
\end{tabular}

The classification results demonstrate that the model has predictive accuracy $93,9 \%$ in overall.

\section{CONCLUSION}

The audit report communicates the auditor's findings to market participants and plays a crucial role in warning financial statement users of impending going concern problems. Issuing a going concern opinion, however, means that the auditor must be able to objectively evaluate firm performance and withstand any client pressure to issue a clean opinion. In every audit, the auditor has a responsibility to evaluate whether there is substantial doubt about client's ability to continue as going concern.

While auditors are required to perform a going concern analysis on each audit engagement, and while they have demonstrated skill in identifying troubled firms, users must realize that an unmodified opinion has no guarantee of financial viability. Most accounting professionals agree that in most cases when audit has failed to uncover material misstatements and the wrong type of audit opinion is issued, a legitimate question may be raised whether the exercised due-care. According to Generally Accepted Auditing Standards, auditors have to be professionals responsible for fulfilling their duties diligently and carefully. Also the audit is to be performed by auditors having adequate technical training and proficiency. Turkey, as an emerging capital market, needs auditing profession to be improved.

This paper provides evidence that a logistic regression model using publicly available financial data predicts whether an auditor will issue a going concern opinion prior to financial distress. Therefore, the objective of this study is to investigate whether the auditors issue going concern opinion by examining the financial data one year prior to financial distress. Logistic regression analysis is applied to test the model of audit opinion decision with a sample of financially distressed firms operating in manufacturing sector in Istanbul Stock Exchange (ISE) between the period of 1998-2006. The results reveal that the audit opinions of distressed firms indicate the auditors fail to issue audit opinions one year prior to failure. Audit reports of distressed firms do not reflect the truth of bad financial indicators.

The model developed to test the opinion decisions of distressed firms reveals that fixed asset turnover, EBIT_Total Assets and BIG4 variables are the distinguishing variables for audit opinion decisions. The explanatory power of significant variables and the overall predictive accuracy of the model are found to be $47,1 \%$ and $93,9 \%$ respectively.

While analyzing the types of audit reports of distressed companies, this study also shows that small audit companies are reluctant to disclose audit opinions other than unqualified. Indeed, many companies in the year prior to bankruptcy receive an audit report in which going concern uncertainty is not disclosed.

Further research that examines the audit opinions both financially distressed and healthy firms will continue to broaden our focus of more rigorous analysis of opinion decisions. Doing so will result in some additional and helpful information for regulators, users and auditors. 


\section{AUTHOR INFORMATION}

Burcu Adiloğlu, Miss Adiloğlu is research and teaching assistant at the Department of Accounting in Istanbul University. She is graduated from Nişantaşı Anatolian High School in 2000. Adiloğlu got her B.Sc. degree from the Istanbul University, Faculty of Business Administration in 2004. She received her M.S. degree from Istanbul University, Accounting Department in 2006. She got $\mathrm{PhD}$. degree in department of accounting at the same university in 2010. Her research interests include auditing, financial accounting, cost accounting and managerial accounting. She works as a research and teaching assistant since 2005 and teaches financial accounting, auditing, cost accounting and managerial accounting. Email: adiloglu@istanbul.edu.tr

Bengü Vuran, Miss Vuran is research and teaching assistant the Department of Finance in Istanbul University. Vuran got her B.Sc. degree from the Istanbul University, Faculty of Business Administration in 1999. She received her M.S. degree from Istanbul University, Finance Department in 2002 with a thesis on the performance measurement of mutual funds. She got $\mathrm{PhD}$. degree in department of finance at the same university in 2008. She works as a research assistant since 2001 and teaches financial management, corporate finance, international finance, capital markets and financial security valuation. E-mail: benguv@istanbul.edu.tr

\section{REFERENCES}

1. Altman, E. (1982). Accounting Implications of Failure Prediction Models. Journal of Accounting,Auditing and Finance, 4-19.

2. Altman, E., \& McGough, T. (1974, December). Evaluation of a Company as a Going-Concern. Journal of Accountancy, 50-57.

3. American Accounting Association,(1973) Committee on Basic Auditing Concepts, A Statement of Basic Auditing Concepts",Sarasota, FL.

4. Arens, A.A., Randal J. Elder, Mark S. Beasley; Auditing and Assurance Services, An Integrated Approach, Pearson Education, 11. Edition, Pearson Education, New Jersey, 2006.

5. Chen, K., \& Church, B. (1992). Default on Debt Obligations and The Issuance of Going-Concern Opinions. A Journal of Practice and Theory, 11 (2), 30-49.

6. Dopuch, N., Holthausen, R., \& Leftwich, R. W. (1987). Predicting Audit Qualifications With Financail and Market Variables. The Accounting Review , 62 (3), 431-454.

7. Hopewood, W., McKeown, J., \& Mutchler, J. (1994). A Reexamination of Auditor versus Model Accuracy Within the Context of The Going-Concern Opinion Decision. Contemporary Accounting Research (Spring), 409-431.

8. International Standard on Auditing (ISA) -570 "Going Concern", International International Auditing and Assurance Standards Board (IAASB), 2009.

9. Lennox, C. (1999). The Accuracy and Information Content Audit Reports in Predicting Bankruptcy. Journal of Business, Finance and Accounting , 26 (5/6), 757-778.

10. Levitan, A., \& Knoblett, J. (1985). Indicators of Exceptions to the Going-Concern Assumptions. Auditing: A Journal of Practice and Theory, 5 (1), 26-39.

11. Messier, W.F., Glover, S., Prawitt, D., Auditing and Assurance Services, A Systematic Approach, 6. Edition, Mc.Grawhill, New York, 2008.

12. Miglani, S., K. Ahmed, D. Henry (2010), “Corporate Governance and Financial Distress: Evidence from Australia" Paper presented at the Accounting and Finance Association of Australia and New Zealand (AFAANZ) Conference, Christchurch, New Zealand., 1-55

13. Mutchler, J. (1985). A Multivariate Analysis of The Auditor's Going Concern Opinion Decisions. Journal of Accounting Research , 35 (2), 668-682.

14. Mutchler, J. F. (1986). Emprical Evidence Regarding the Auditor's Going-Concern Opinion Decision. Auditing: a journal of Practice \& Theory , 6, 148-163. 
NOTES 